\title{
IRON AND SULFUR IN THE PRE-BIOLOGIC OCEAN
}

\author{
JAMES C.G. WALKER
}

Space Physics Research Laboratory, Department of Atmospheric and Oceanic Science, The University of Michigan, Ann Arbor, Michigan 48109 (U.S.A.)

PETER BRIMBLECOMBE

School of Environmental Sciences, University of East Anglia, Norwich NR4 7TJ (Gt. Britain)

(Received October 25, 1983; revision accepted October 12, 1984)

\section{ABSTRACT}

Walker, J.C.G. and Brimblecombe, P., 1985. Iron and sulfur in the pre-biologic ocean. Precambrian Res., 28: 205-222.

Tentative geochemical cycles for the pre-biologic Earth are developed by comparing the relative fluxes of oxygen, dissolved iron, and sulfide to the atmosphere and ocean. The flux of iron is found to exceed both the oxygen and the sulfide fluxes. Because of the insolubility of iron oxides and sulfides the implication is that dissolved iron was fairly abundant and that oxygen and sulfide were rare in the atmosphere and ocean. Sulfate, produced by the oxidation of volcanogenic sulfur gases, was the most abundant sulfur species in the ocean, but its concentration was low by modern standards because of the absence of the river-borne flux of dissolved sulfate produced by oxidative weathering of the continents.

These findings are consistent with the geologic record of the isotopic composition of sedimentary sulfates and sulfides. Except in restricted environments, the sulfur metabolism of the earliest organisms probably involved oxidized sulfur species not sulfide.

\section{INTRODUCTION}

Concentrations of dissolved iron are generally low in natural waters on the modern Earth because oxidized iron is insoluble. Weathering of ironbearing minerals under an oxygenated atmosphere results in the precipitation of iron as insoluble iron (III) oxides and hydroxides (Holland, 1978). Appreciable concentrations of dissolved iron are found only in anoxic environments such as sediments rich in organic matter. Reactive iron in these environments is reduced and enters solution as $\mathrm{Fe}^{++}$(Froelich et al., 1979).

Iron sulfide minerals are also insoluble, so appreciable concentrations of dissolved iron are found only in waters deficient in sulfide. The inverse relationship between dissolved iron and sulfide in interstitial waters of the 
anoxic sediments of Greifensee, Switzerland (Emerson, 1976; Emerson and Widmer, 1978) is shown in Fig. 1. Concentrations of dissolved iron reach values of several hundred micromoles $\mathrm{l}^{-1}$ in these waters, and the activity of bisulfide ions is restricted to values below $10^{-6}$ by the precipitation of iron sulfide minerals.

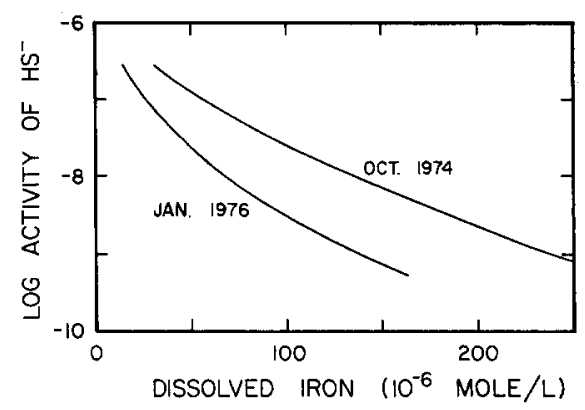

Fig. 1. Inverse relationship of dissolved iron and sulfide in the anoxic pore waters of the sediments of Greifensee, Switzerland. The data are from Emerson (1976) and Emerson and Widmer (1978). These authors show that the activity of sulfide is limited, in the presence of abundant dissolved iron, by precipitation of various iron sulfide minerals.

In anoxic marine sediments, on the other hand, microbial reduction of abundant dissolved sulfate provides a source of sulfide generally far in excess of the rate of supply of reactive iron (Berner, 1971, 1982). Sulfide concentrations in the interstitial waters of the sediments are high and concentrations of dissolved iron very low.

On the modern Earth, therefore, deficiency of dissolved iron in oxygenated waters results from the insolubility of oxidized iron (Gordon et al., 1982). Its deficiency in many anoxic waters results from the insolubility of iron sulfide and the abundance of sulfide produced by bacterial sulfate reduction. Oxygenated waters were rare or absent on the early Earth (Kasting et al., 1979; Kasting and Walker, 1981; Walker et al., 1983; see Walker, 1977a for older references). The Archean ocean may have contained abundant dissolved iron or abundant dissolved sulfide, but not both (Holland, 1973; Drever, 1974). Here we consider which was likely to have been more abundant. First we examine an imaginary titration of iron against oxygen in the ocean. Then we examine an imaginary titration of iron against sulfide. In each of these titrations, the chemical species with the greatest rate of supply would have dominated.

Our approach is to consider the geochemical cycles of the elements in question on the modern Earth. We then eliminate from the cycles those processes that were probably or certainly absent from the Earth before the proliferation of life. Biological processes are the clearest candidates for elimination. We then analyze the diminished geochemical cycle, assuming that it is applicable to the early Earth, without necessarily trying to adjust the rates of the remaining, abiological processes. This procedure is 
conservative in the sense that it does not require very speculative extrapolations of rates into the distant past. It must, of course, lead to a very crude approximation to the geochemical cycles of the early Earth, both because many of the important rates are not well known even today, and because many of them undoubtedly have changed with time.

\section{TITRATION OF IRON AGAINST OXYGEN}

Figure 2 illustrates, schematically, the biogeochemical cycle of oxygen on the modern Earth. Annual rates are expressed in moles of oxygen $\left(\mathrm{O}_{2}\right)$ or as an equivalent reducing power. The oxygen cycle today is dominated by production of oxygen in photosynthesis at a rate of $10^{16} \mathrm{~mol} \mathrm{y}^{-1}$ and consumption of oxygen in respiration and other biological processes at an almost equal rate (Walker, 1980). A very much smaller flux of oxygen, about $2 \times 10^{13} \mathrm{~mol} \mathrm{y}^{-1}$, is consumed by weathering reactions on the continents, which yield among other products a flux of $5 \times 10^{12} \mathrm{~mol} \mathrm{y}^{-1}$ of oxygen in oxidized iron from the continents to the sea (Garrels and Mackenzie, 1971). Oxygen in the ocean is consumed also at a rate of $2 \times 10^{12}$ mol $y^{-1}$ by reaction with dissolved ferrous iron released in hydrothermal systems on the sea floor (Wolery and Sleep, 1976). Oxidized iron is removed from the ocean by incorporation into sediments. There is a small additional consumption of photosynthetic oxygen, some $10^{12} \mathrm{~mol} \mathrm{y}^{-1}$, in the course of photochemical reactions within the atmosphere that lead to the oxidation of reduced volcanic gases (Holland, 1978). Finally, there is a net source of abiogenic oxygen that corresponds to the escape of hydrogen from the top of the atmosphere to space (Walker, 1977a).

The corresponding geochemical cycles on the prebiological Earth are illustrated in Fig. 3. Photosynthesis and respiration are of course absent, and the only source of free oxygen in the atmosphere (or ocean) is the

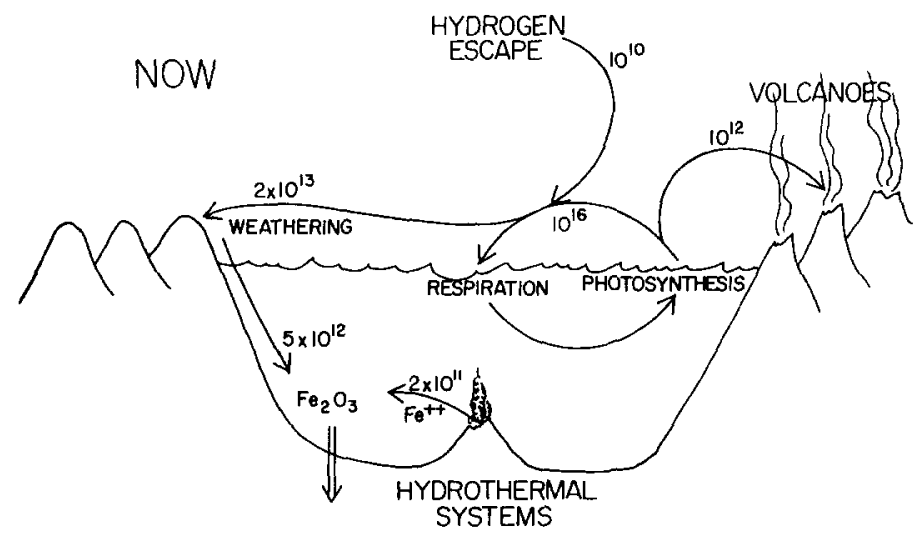

Fig. 2. Schematic representation of the biogeochemical cycles of oxygen on the modern Earth. Annual rates are expressed in moles of oxygen or equivalent reducing power. 
photolysis of atmospheric water vapor followed by the escape of hydrogen to space. The rate of this process depends on the mixing ratio of water vapor in the stratosphere and thus on the temperature of the tropopause (Walker, 1977a). Limits on this abiological source of oxygen on the early Earth have been discussed by Walker (1978). The oxygen source in the present day atmosphere is about $10^{10} \mathrm{~mol} \mathrm{y}^{-1}$. The source was probably smaller in the Archean because of lower solar luminosity (Gough and Weiss, 1976; Gough, 1977; Newman and Rood, 1977; Walker, 1982).

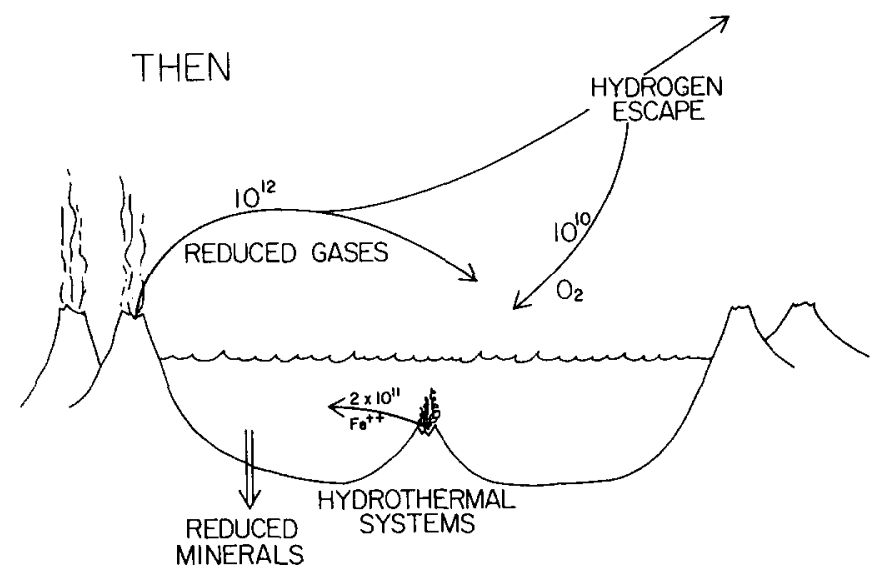

Fig. 3. Presumed geochemical cycles of oxygen and reduced species on the prebiological Earth.

On the other hand, the volcanic source of reduced gases and the hydrothermal source of reduced, dissolved iron were probably larger on the early Earth, with its higher heat flow. It seems clear, therefore, that oxygen in the prebiological atmosphere was overwhelmed by volcanic reduced gases as in turn the oxygen in the prebiological ocean was overwhelmed by dissolved, reduced iron. The concentration of dissolved iron in the prebiological ocean was therefore not limited by oxygen. This finding is consistent with mineralogic evidence for the precipitation of Archean and early Proterozoic banded iron-formations from anoxic waters (Klein and Bricker, 1977).

Consumption of oxygen in subaerial weathering processes does not appear in Fig. 3. We have deleted this process because of geochemical and sedimentological evidence that continental weathering and erosion had little impact on the composition of either the ocean or sedimentary rocks on the early Earth (Lowe, 1980, 1982; Veizer, 1983). It appears that areas of exposed continental land mass in the Archean were small (Campbell, 1983; Moorbath, 1983).

\section{TITRATION OF IRON AGAINST SULFIDE}

Pyrite $\left(\mathrm{FeS}_{2}\right)$ is the dominant sulfide bearing mineral in sea floor basalt. Dissolution of pyrite in sea water interactions with hot basalt must there- 
fore yield dissolved iron as fast as dissolved sulfide. But basalts contain much more abundant iron-bearing minerals that also release iron to solution (Edmond et al., 1979a) without releasing sulfide. So the flux of iron from sea floor basalts to the Archean ocean would have exceeded the flux of sulfide. The hydrothermal solutions of modern mid-ocean ridge hot springs are balanced close to the transition between excess iron and excess sulfide (Edmond et al., 1979a), but much of the sulfide today is produced by reduction of oceanic sulfate. The question of sulfate concentrations in the Archean ocean is taken up below.

The same argument applies to any material supplied to the ocean by continental weathering Because of the relative geochemical abundances of iron and sulphur (12:1) (Ronov and Yaroshevskiy, 1967) and because sulfide is present mainly in combination with iron, the rate of supply of iron must exceed the rate of supply of sulfide, unless the iron is immobilized by oxidation.

The present rate of release of sulfur dioxide from volcanoes is estimated to be about 0.15 to $0.25 \times 10^{12} \mathrm{~mol} \mathrm{y}^{-1}$ (Stoiber and Jepsen, 1973; Zehnder and Zinder, 1980; Berresheim and Jaeschke, 1983). Hydrogen sulfide is much less abundant than sulfur dioxide in most volcanic gases today (Anderson, 1975), and it would have been even rarer in Archean volcanic emissions if they were hotter (Heald et al., 1963). Furthermore we show below that $\mathrm{H}_{2} \mathrm{~S}$ would probably have undergone photochemical oxidation in the Archean atmosphere even in the absence of oxygen.

It seems likely, therefore, that the global rate of supply of dissolved iron to the Archean ocean exceeded the rate of supply of sulfide. In average sea water, therefore, the iron concentration would have been relatively high and the sulfide concentration very low. Estimates of the dissolved iron concentration in the waters that deposited banded iron-formations are above $10^{-4} \mathrm{~mol} \mathrm{l}^{-1}$ (Holland, 1973; Drever, 1974; Ewers, 1980). Corresponding bisulfide activities could have been below $10^{-8}$ (see Fig. 1). Any volcanogenic sulfide debouching into such an ocean would have precipitated immediately as iron sulfide minerals. Such an association of sulfide rich sediments of Archean age with volcanic vents has been noted by Cameron and Garrels (1980). In restricted environments, particularly those with large sources of volcanogenic sulfide, the titralion may have been reversed to give locally high sulfide and low iron concentrations.

\section{OXIDATION OF SULFUR}

In this section we consider the fate of the sulfur bearing gases, $\mathrm{H}_{2} \mathrm{~S}$ and $\mathrm{SO}_{2}$, that were released from volcanoes to the Archean hydrosphere and atmosphere. We show that volcanic $\mathrm{H}_{2} \mathrm{~S}$ would have been oxidized by photochemical processes in the atmosphere and so was not likely to reverse the titration of iron against sulfide in the Archean ocean. We also show that volcanic sulfur gases were a potentially important source of sulfate for the ocean. 
Note first that thermodynamic considerations favor the oxidation of sulfur compounds, as the equilibria

$\mathrm{H}_{2} \mathrm{~S}+2 \mathrm{O}_{2} \rightleftharpoons \mathrm{H}_{2} \mathrm{SO}_{4}$

$\mathrm{SO}_{2}+\mathrm{H}_{2} \mathrm{O}+0.5 \mathrm{O}_{2} \rightleftharpoons \mathrm{H}_{2} \mathrm{SO}_{4}$

lie to the right for oxygen partial pressures greater than about $10^{-60}$ bar (at water vapor partial pressures of 0.01 bar). Sulfate would therefore have been stable in the Archean atmosphere. It is necessary, however, to consider whether there were kinetic mechanisms for the oxidation of volcanogenic hydrogen sulfide and sulfur dioxide.

Wet removal of hydrogen sulfide by precipitation would have been slow, because the gas is not soluble enough to be effectively scavenged. On the other hand, transfer of hydrogen sulfide from the atmosphere to the ocean would have been enhanced by the reaction with dissolved iron. Most of the hydrogen sulfide would have been rapidly oxidized by homogeneous radical reactions in the atmosphere. As suggested by Van der Wood and Thiemens (1980), the oxidation reactions would probably have started with attack by the $\mathrm{OH}$ radical. Concentrations of $\mathrm{OH}$ in excess of $10^{6} \mathrm{~cm}^{-3}$ at ground level could quite easily have been sustained by photolysis of water vapor (Kasting and Walker, 1981). With a rate constant of $\sim 5 \times 10^{-12}$ $\mathrm{cm}^{3} \mathrm{~s}^{-1}$ (Perry et al., 1976), the reaction

$\mathrm{H}_{2} \mathrm{~S}+\mathrm{OH} \rightarrow \mathrm{HS}+\mathrm{H}_{2} \mathrm{O}$

would have destroyed hydrogen sulfide in a characteristic time of about $35 \mathrm{~h}$. In an early atmosphere with a high concentration of hydrogen atoms (about $3 \times 10^{9} \mathrm{~cm}^{-3}$, Kasting and Walker, 1981) the HS would be removed by the reaction

$\mathrm{HS}+\mathrm{H} \rightarrow \mathrm{H}_{2}+\mathrm{S}$

Atomic sulfur would probably be removed from the atmosphere by dry deposition or incorporation into particulates. The reactions

$\mathrm{S}+\mathrm{OH} \rightarrow \mathrm{SO}+\mathrm{H}$

$\mathrm{SO}+\mathrm{OH} \rightarrow \mathrm{SO}_{2}+\mathrm{H}$

are possible, but any sulfur monoxide produced in the atmosphere was more likely to suffer photolysis back to elemental sulfur

$\mathrm{SO}+\mathrm{h} \nu \rightarrow \mathrm{S}+\mathrm{O}$

The likely fate of volcanogenic hydrogen sulfide entering the atmosphere, then, was photochemical oxidation to elemental sulfur. The elemental sulfur, after deposition from the atmosphere, may have undergone further oxidation in the ocean. 
The much more abundant volcanogenic sulfur dioxide would also have suffered attack by the $\mathrm{OH}$ radical

$$
\mathrm{SO}_{2}+\mathrm{OH} \rightarrow \mathrm{HSO}_{3}
$$

the rate constant for this reaction is $2 \times 10^{-10} \mathrm{~cm}^{3} \mathrm{~s}^{-1}$ (CODATA, 1979). With the $\mathrm{OH}$ concentration predicted by Kasting and Walker (1981), a residence time of 3.6 days results for the photochemical oxidation of sulfur dioxide. The subsequent conversion of $\mathrm{HSO}_{3}$ to a sulfate aerosol is generally believed to proceed rapidly, even in the absence of oxygen (Winick and Stewart, 1980). The possibility that abundant atomic hydrogen could hinder this reaction has not been quantitatively evaluated. The sulfate aerosol would be removed from the atmosphere by rain to provide a source of sulfate to the ocean. Both wet removal of sulfur dioxide by rain and dissolution in the ocean could have been important also.

When the reduced sulfur source exceeded the production of oxidant or where the sulfur dioxide arose from submarine volcanism there could have been large additions of S(IV) to the oceans (Skyring and Donnelly, 1982). Sulfite, S(IV), is not stable with respect to either sulfide or sulfate in alkaline solution (Berner, 1971). Thus oxidation of sulfite could proceed through a double decomposition that might be written

$$
4 \mathrm{SO}_{3}=3 \mathrm{SO}_{4}=+\mathrm{S}^{=}
$$

although it would probably be mediated by photochemical or catalytic pathways. In addition sulfite and elemental sulfur in the early ocean would compete with ferrous iron for any oxidants that entered solution. Such oxidants would include oxygen and a variety of oxidizing chemical species produced in the atmosphere by photochemical processes (Kasting and Walker, 1981). Oxidants may also have been produced by photochemical processes in the surface layers of the ocean. In particular, ferric iron may have been produced by irradiation of sea water rich in dissolved ferrous iron (Cairns-Smith, 1978; Braterman et al., 1983). Sulfite may have been directly oxidized by a similar photochemical process (Hayon et al., 1972) or photochemically produced ferric iron may have served as an intermediary.

In summary, much volcanogenic sulfur dioxide would probably have been photochemically oxidized in the atmosphere to sulfate, which would have been washed into the ocean. Any sulfite or elemental sulfur that escaped oxidation in the atmosphere would probably have been oxidized to the thermodynamically stable S(VI) state by chemical and photochemical reactions in the surface layers of the ocean.

\section{SULFATE BUDGET}

If we assume that any sulfide released to the early ocean was precipitated immediately as iron sulfide minerals, we are left with the budget of sulfate 
to consider. Biological production of sulfate by photosynthetic bacteria could not have been globally important in the absence of dissolved sulfide for bacteria to oxidize. The only important source of sulfate would have been volcanogenic sulfur gases that were photochemically oxidized in the atmosphere and the surface ocean. As shown in Fig. 4, the modern source

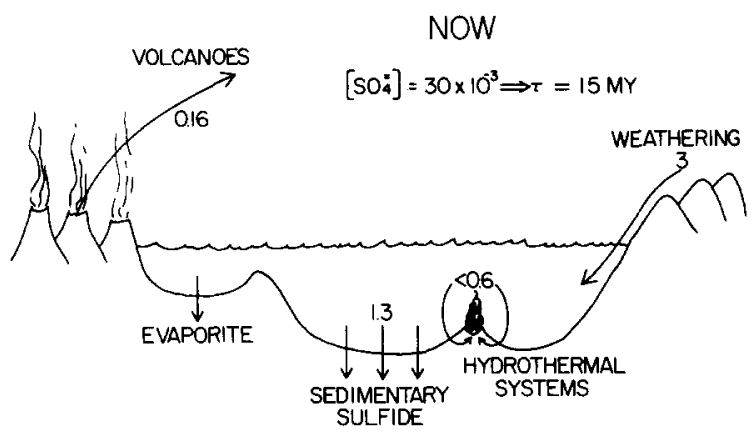

Fig. 4. Schematic representation of the biogeochemical cycles of sulfate on the modern Earth. Rates of exchange are expressed in units of $10^{12} \mathrm{~mol} \mathrm{~S} \mathrm{y}^{-1}$. The present day concentration of sulfate in sea water, equal to $30 \times 10^{-3} \mathrm{~mol} \mathrm{l}^{-1}$, implies a residence time of sulfate in the ocean, $\tau$ of $15 \mathrm{Ma}$. Because sulfate evaporites are not forming at significant rates today it appears that the budget is unbalanced and that sulfate is accumulating slowly in the ocean.

of volcanogenic sulfur gases is estimated at about $0.15 \times 10^{12} \mathrm{~mol} \mathrm{y}^{-1}$ (Zehnder and Zinder, 1980). The source might well have been larger on the early Earth with its higher heat flow and presumably higher rate of volcanic activity.

A potentially important sink for oceanic sulfate was the reaction of sea water with hot basalt in sea floor hydrothermal systems. Sulfate is totally removed from sea water in modern hydrothermal systems (Edmond et al., 1979b). In part the sulfate appears to be precipitated as anhydrite $\left(\mathrm{CaSO}_{4}\right)$, which is relatively insoluble at high temperature (Holland, 1978). In part, the sulfate is reduced to sulfide by reaction with iron and precipitated as pyrite (Holland, 1978; Edmond et al., 1979a; McDuff and Edmond, 1982). Because anhydrite is not found in weathered basalts on the sea floor it is believed to be leached out of the rock in subsequent low-temperature weathering processes. The net flux of sulfur from the ocean into the sea floor is below the value that would be calculated from data on high temperature interactions alone (Wolery and Sleep, 1976). From considerations of the oxidation-reduction balance in the exogenic system, Wolery and Sleep set an upper limit of $0.6 \times 10^{12} \mathrm{~mol} \mathrm{y}^{-1}$ on the rate at which sulfate is reduced by interaction with sea floor basalt. The actual rate may well be less.

Estimates of the heat carried out of the oceanic crust by advecting sea water suggest that the rate of circulation is sufficient to process the entire ocean through sea floor hydrothermal systems in an average time of $10 \mathrm{Ma}$ 
(Wolery and Sleep, 1976). This time was presumably smaller on the early Earth, but we can use it for a preliminary estimate of the effect of sea floor hydrothermal activity on oceanic sulfate. Assume that hydrothermal interactions removed all of the dissolved sulfate from circulating sea water. The residence time of dissolved sulfate in the ocean would then have been $10 \mathrm{Ma}$. The total mass of sulfate in the ocean would have been the product of this time and the estimated source of $0.15 \times 10^{12} \mathrm{~mol} \mathrm{y}^{-1}$. The resultant mass of oceanic sulfate is $0.15 \times 10^{19} \mathrm{~mol}$. Today there are $4.4 \times 10^{19} \mathrm{~mol}$ as sulfate in the ocean, at an average concentration of $30 \times 10^{-3} \mathrm{~mol} \mathrm{l}^{-1}$ (Broecker, 1974). The above estimate represents $\sim 3 \%$ of the present value, assuming that the volume of the ocean has not changed with time (Walker, $1977 \mathrm{a}, \mathrm{b}$; Stevenson, 1983). A larger volcanogenic source of sulfur gases would have yielded higher concentrations, but more sea floor hydrothermal activity would have yielded lower concentrations. If volcanic and hydrothermal activity changed in proportion, the estimate of concentration would not be affected.

The much higher sulfate concentrations of the modern ocean are, of course, sustained in the face of hydrothermal removal by the large flux of dissolved sulfate (Fig. 4) provided by oxidative weathering of the continents (Meybeck, 1979; Zehnder and Zinder, 1980). We assume that the continental contribution was minor on the Archean Earth (Lowe, 1980, 1982; Veizer, 1983).

Today there is a substantial sink of oceanic sulfate, some $1.25 \times 10^{12}$ mol $\mathrm{y}^{-1}$, which results from the reduction of sulfate by microorganisms in anaerobic sediments and precipitation of iron sulfide. This removal process would have been absent on the prebiological Earth. During the course of Earth history there has also been substantial removal of sulfate from the ocean by the formation of evaporite deposits. This sink is at present small because there are few shallow, partially enclosed seas located in arid regions. It is possible that sulfate is accumulating in the modern ocean because of the rarity of evaporitic basins (Berner, 1972). On the Archean Earth, with few continents (Campbell, 1983; Moorbath, 1983), there was presumably

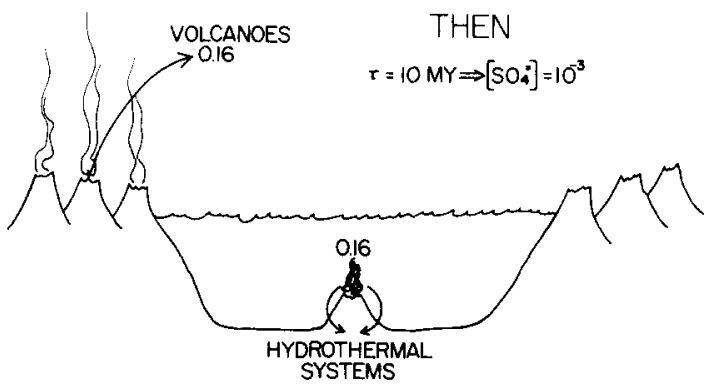

Fig. 5. The presumed geochemical cycles of sulfate on the prebiological earth. A residence time of $10 \mathrm{Ma}$ against the removal of sulfate in sea floor hydrothermal systems would imply a concentration of sulfate in sea water equal to $10^{-3} \mathrm{~mol} \mathrm{l}^{-1}$. 
less opportunity for the formation of extensive evaporite deposits. We therefore neglect the evaporitic sink for oceanic sulfate on the early Earth assuming that the production and weathering of evaporites were in steady state. A low sulfate concentration does not prohibit the formation of evaporites such as gypsum as it is possible that calcium concentrations were higher in the Archean ocean (Walker, 1983) thus maintaining a high calciumsulfate ion product.

The geochemical balance illustrated in Fig. 5 is based on the assumption that all of the sulfate involved in hydrothermal interactions on the early Earth was reduced to sulfide and precipitated as pyrite. Is this assumption reasonable, when such is not the case today? The upper limit deduced by Wolery and Sleep (1976) on the rate of sulfate reduction in modern hydrothermal interactions is less than one-fifth of their estimate of the total amount of sulfate circulating through sea floor hydrothermal systems. Qualitative theoretical arguments suggest that total removal of sulfate is a reasonable consequence of low sulfate concentrations in the circulating sea water. Data on the concentrations of stable sulfur isotopes in Archean sediments also support the assumption of complete removal of sulfate.

Consider first that hot sea water reacts with iron silicate minerals to release ferrous ions to solution (MacGeehan dna MacLean, 1980). These ions consume the oxygen released by the equilibrium reaction

$2 \mathrm{H}^{+}+\mathrm{SO}_{4}=\mathrm{H}_{2} \mathrm{~S}(\mathrm{aq})+2 \mathrm{O}_{2}$

A large supply of sulfate relative to ferrous iron results in a relatively high oxygen fugacity and the stability of $\mathrm{SO}_{4}{ }^{=}$relative to $\mathrm{H}_{2} \mathrm{~S}$ (Ohmoto, 1972). Conversely, a relatively small sulfate supply, corresponding to low sulfate concentrations in sea water, yields a low $\mathrm{O}_{2}$ fugacity and results in the stability of sulfide. If iron (in the +2 oxidation state) is sufficiently abundant relative to sulfate to reduce all sulfate to sulfide, the sulfide will precipitate as iron sulfide minerals, resulting in virtually complete removal of the sulfur from the circulating sea water.

Consider now the isotopic evidence preserved in evaporitic sulfate minerals. Abiotic reduction of sulfate to sulfide fractionates in favor of the light isotope (Ohmoto, 1972), leaving the residual sulfate enriched in the heavy isotope. Incomplete reduction of the sulfate in circulating sea water would therefore remove the light isotope preferentially, leaving average sea water enriched in the heavy isotope (Edmond et al., 1979b). But evaporitic sulfates, which reflect the isotopic composition of sea water at the time of their deposition (Holser and Kaplan, 1966), show isotopic compositions close to the primordial or mantle value during the Archean (Schidlowski, 1979; Skyring and Donnelly, 1982). The process that removed sulfate from the Archean ocean must therefore have been isotopically unselective. Since sea floor hydrothermal interactions must have been an important component of the sulfur budget in the Archean ocean (Veizer et al., 1982) 
we conclude that these interactions must have resulted in complete not partial reduction of the sulfate.

The geologic record of the isotopic composition of sulfide minerals in hydrothermal deposits believed to have formed at or near the sea floor also suggests that the concentration of sulfate in sea water has increased over time. In recent examples of these deposits, the sulfide is enriched in the heavier isotope by a few per mil relative to the primordial value (Arnold and Sheppard, 1981; Skirrow and Coleman, 1982). This enrichment is attributed to a mixture of mantle sulfide, with isotopic composition close to the primordial value $\left(\delta^{34} \mathrm{~S} \sim 0 \%\right.$ o), and sulfide derived from the reduction of sea water sulfate $\left(\delta^{34} \mathrm{~S} \sim 20 \%\right.$ ) . The sulfide derived from reduction of sea water sulfate has been fractionated in favor of the light isotope. Archean and early Proterozoic hydrothermal sulfides show little isotopic fractionation (Schidlowski et al., 1983). Their average isotopic composition is close to that of the mantle source and also to that of Archean sulfate evaporites. If the sea water sulfate had undergone partial reduction in the Archean, as it appears to do today, and if it had made the same relative contribution to the total sulfide in hydrothermal deposits, the Archean deposits would have been enriched in the light isotope. The absence of differences in isotopic composition between the mantle, sea water sulfate, and hydrothermal sulfides indicates either that the sea water contribution to the hydrothermal deposits was negligible or that the reduction of sea water sulfate was complete and, therefore, caused little fractionation. Either interpretation implies that the concentration of sulfate in the Archean ocean was much lower than it is today. The Archean hydrothermal fluids, lacking a large contribution of sulfide derived from reduction of sea water sulfate would, therefore, have contained excess iron, as we assumed in an earlier section. So hydrothermal reduction of sea water sulfate would not have altered the predominance of iron in the oceanic titration of iron against sulfide.

\section{SEDIMENTARY SULFUR}

The isotopic composition of sedimentary sulfides of Archean age is, on average, close to the primordial value, although some deposits show considerable scatter (Goodwin et al., 1976; Schidlowski, 1979; Cameron and Garrels, 1980; Skyring and Donnelly, 1982; Veizer, 1983; Thode and Goodwin, 1983; Hattori et al., 1983a, b). This scatter is attributed to isotopic fractionation in the reduction of limited amounts of oxidized sulfur by biological or abiological processes in partially closed systems. The data are therefore consistent with our expectation of sulfate at low concentrations as the most abundant sulfur species in solution.

Phanerozoic and recent sedimentary sulfides show considerable scatter in isotopic composition also (Holser and Kaplan, 1966; Ashendorf, 1980; Burne et al., 1982), but they are invariably enriched in the light isotope as compared with sea water sulfate. This enrichment is a consequence of 
biological sulfate reduction, which favors the light isotope (Chambers and Trudinger, 1978). The absence of a similar fractionation in the sulfides of Archean sediments implies either that these sulfides were not biogenic, or that biological sulfate reduction on the Archean Earth did not cause significant isotopic fractionation.

Cameron (1982) called attention to the observation that isotopic fractionation in biological sulfate reduction is small when the ambient sulfate concentration is low. Presumably, this is another example of the fact that isotopic fractionation is possible only when there is excess sulfate. It has been found in laboratory studies that microbial sulfate reducers do not yield isotopically light sulfides when grown in media containing sulfate concentrations as low as $10^{-3} \mathrm{~mol} \mathrm{l}^{-1}$ (Harrison and Thode, 1958; Chambers and Trudinger, 1978). This is the value we estimated, from considerations of the sulfur budget, for the sulfate concentration in the pre-biological ocean. It does not seem possible, therefore, on the basis of average isotopic composition alone, to distinguish between abiogenic, presumably hydrothermal, sulfide in Archean sediments and biogenic sulfide produced under conditions of low sulfate concentration. It is possibly significant that the large numbers of North American shales of Archean and early Proterozoic age analyzed by Cameron and Garrels (1980) revealed low concentrations of both sulfide and organic carbon in most of the Archean samples. They argued that the samples with high sulfide and organic carbon concentrations were associated with volcanic vents.

Cameron (1982) presented the evolution of the isotopic composition of sulfide in argillaceous sediments of Archean and early Proterozoic age from South Africa. His data show a distinct change in the isotopic composition between 2350 and $2200 \mathrm{Ma}$ ago. It is at this time that sulfides strongly enriched in the light isotope first appear in the geologic record. As Cameron suggests, this change could reflect biological reduction of sulfate to sulfide with the isotopic fractionation becoming possible for the first time because of increased sulfate concentrations in the ambient waters. Increased sulfate concentrations could be the result of an increased supply of sulfate from continental weathering in the presence of an increasingly oxygenic atmosphere. The first indications of oxidative weathering in the geological record date from about this time (Walker et al., 1983). The increase in the partial pressure of oxygen in the atmosphere, in turn, is believed to result from increased production of oxygen by photosynthetic organisms (Knoll, 1979).

In summary, then, increased biological productivity may have resulted from continental emergence and stabilization at the end of the Archean. Increased productivity yielded a more oxygenic atmosphere, so that continental weathering supplied more sulfate to the ocean. The resulting increase in sulfate concentration enabled biological sulfate reduction to fractionate in favor of the light isotope in the production of sedimentary sulfides. 
Sulfate evaporites of early and middle Proterozoic age are enriched in the heavy isotope by amounts comparable to those of more recent deposits (Claypool et al., 1980; Skyring and Donnelly, 1982; Cameron, 1983). This change from the unfractionated sulfate of the Archean to the heavy sulfate of the Proterozoic may have been a consequence of either biological or abiological reduction of sulfate to sulfide. While higher sulfate concentrations permit isotopic fractionation in the course of biological sulfate reduction, they also make possible the incomplete reduction of the sulfate in hydrothermal interactions on the sea floor, thereby causing the abiological process to fractionate in favor of isotopically light sulfide and isotopically heavy sulfate also. Even today, it is not clear to what extent the relatively heavy isotopic composition of sea water is a consequence of biological rather than abiological fractionation mechanisms (Edmond et al., 1979b).

Although Cameron's (1982) data from South Africa show isotopically light sulfide appearing in the early Proterozoic, as would be expected for biological sulfate reduction in the presence of larger sulfate concentrations, most lower Proterozoic sulfide seems to be enriched in the heavy isotope (Cameron and Garrels, 1980; Skyring and Donnelly, 1982). Cameron and Garrels raised the question of the location of isotopically light sulfur at a time when both oceanic sulfate and sedimentary sulfide were enriched in the heavy isotope. Heavy oceanic sulfate could not have been a consequence of the deposition of light sedimentary sulfide if the sedimentary sulfide was heavy also. This observation seems to suggest that the enrichment of

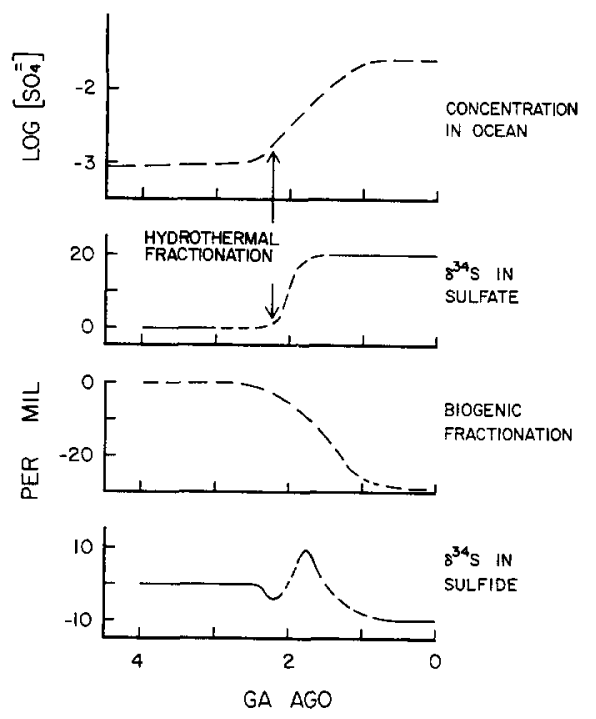

Fig. 6. A tentative illustration of the variation with time in the concentration of dissolved sulfate in the ocean, the isotopic compositions of sulfur both in evaporite minerals and in sedimentary sulfides, and the biogenic fractionation of sulfur isotopes, which depends on sulfate concentrations. The solid lines refer to data while the dashed lines are speculative interpolations. 
oceanic sulfate in the heavy isotope was not a consequence of biological sulfate reduction. It may instead have been a result of hydrothermal interactions with the sea floor. Increasing sulfate concentrations could have resulted in incomplete reduction of sulfate in hydrothermal processes and consequent fractionation to leave isotopically heavy sulfur in the oxidized form (see Fig. 6). According to this suggestion, then, the light sulfur that was missing from both oceans and sedimentary sulfide might have been incorporated into the oceanic crust and mantle. The distributions of isotopic composition of sedimentary sulfides suggest biological sulfate reduction under conditions of occasional sulfate limitation. Low to medium concentrations of sulfate in early Proterozoic sea water would have yielded many environments in which sulfate was in short supply, at least intermittently.

\section{SUMMARY}

It appears that the concentration of dissolved ferrous iron in the Archean ocean was relatively high. The concentration of sulfide ions was, therefore, vanishingly low. Sulfide may not have been the electron donor for the first photosynthetic bacteria. In the absence of a large source of sulfate provided by oxidative weathering of the continents, the concentration of sulfate in sea water was very much lower than that of the present day. The sulfate concentration was determined by a balance between a volcanic source of sulfur gases followed by photochemical oxidation to sulfate and the sink that corresponded to reduction of oceanic sulfate in hydrothermal reactions with hot basalt on the sea floor. The low concentration of sulfate in sea water prevented significant fractionation of the isotopes of sulfur either in hydrothermal or bacterial reduction of sulfate. In consequence, evaporitic sulfates, hydrothermal sulfides, and biogenic sulfide all exhibited the same, primordial isotopic composition. The increase of continentality and of the partial pressure of oxygen in the atmosphere in the early Proterozoic yielded an increase in the flux of sulfate to the ocean and an increasing concentration of oceanic sulfate. As shown in Fig. 6, the increase in concentration may have permitted increasing isotopic fractionation of sulfur in the course of biogenic sulfate reduction. For a period of time, there may have resulted isotopically light sedimentary sulfides of biogenic origin, as suggested by the South African data of Cameron (1982). The increasing sulfate concentration also caused isotopic fractionation in hydrothermal interactions on the sea floor, resulting from partial reduction of sulfate to sulfide. The extraction of isotopically light sulfur from sea water in the hydrothermal interaction caused a positive excursion in the isotopic composition of sea water sulfate, as shown in Fig. 6 and as revealed by the geological record of the later Proterozoic and Phanerozoic. The isotopically heavy sulfides described by Cameron and Garrels (1980) may have been laid down at a time when hydrothermal fractionation had produced isotopically heavy 
sea water, but sulfate concentrations in the ocean were still too low to permit a large biogenic fractionation. This speculative interpretation of the geologic record of the isotopic composition of sedimentary sulfates and sulfides is shown in Fig. 6, where solid lines refer to data and dashed lines are interpolated.

\section{ACKNOWLEDGMENT}

This research was supported in part by the National Aeronautics and Space Administration under Grant Number NAGW-176 and in part by the National Science Foundation under Grant ATM-8209760 to the University of Michigan. This is a contribution of the Precambrian Paleobiology Research Group.

\section{REFERENCES}

Anderson, A.T., 1975. Some basaltic and andesitic gases. Rev. Geophys. Space Phys., 13: 37-55.

Arnold, M. and Sheppard, S.M.F., 1981. East Pacific rise at latitude 21 N: isotopic composition and origin of the hydrothermal sulphur. Earth Planet. Sci. Lett., 56: 14481456.

Ashendorf, D., 1980. Are sulfur isotope ratios sufficient to determine the antiquity of sulfate reduction? Origins of Life, 10:325-333.

Berner, R.A., 1971. Principles of Chemical Sedimentology. McGraw-Hill, New York, NY, $240 \mathrm{pp}$.

Berner, R.A., 1972. Sulfate reduction, pyrite formation and the oceanic sulfur budget. In: D. Dyrssen and D. Jagner (Editors), The Changing Chemistry of the Oceans. Wiley, New York, NY, pp. 347-361.

Berner, R.A., 1982. Burial of organic carbon and pyrite sulfur in the modern ocean: its geochemical and environmental significance. Am. J. Science, 282: 451-473.

Berresheim, H. and Jaeschke, W., 1983. The contribution of volcanos to the global atmospheric sulfur budget. J. Geophys. Res., 88: 3732-3740.

Braterman, P.S., Cairns-Smith, A.G. and Sloper, R.W., 1983. Photo-oxidation of hydrated $\mathrm{Fe}^{++}$- significance for banded iron-formations. Nature, 303: 163-164.

Broecker, W.S., 1974. Chemical Oceanography. Harcourt Brace Jovanovich, New York, NY, 214 pp.

Burne, R.V., Ferguson, J., Fitzsimmons, D., O'Brien, P.E., Plumb, L.A. and Thomas, M., 1982. Isotope studies in the modern environment. Baas Becking Geobiological Laboratory Annual Report, Bureau of Mineral Resources, P.O. Box 3738, Canberra City, ACT 2601, Australia.

Cairns-Smith, A.G., 1978. Precambrian solution photochemistry, inverse segregation and banded iron-formations. Nature, 276: 807-808.

Cameron, E.M., 1982. Sulfate and sulfate reduction in Early Precambrian oceans. Nature, 296: $145-148$.

Cameron, E.M., 1983. Evidence from early Proterozoic anhydrite for sulphur isotopic partitioning in Precambrian oceans. Nature, 304: 54-56.

Cameron, E.M. and Garrels, R.M., 1980. Geochemical composition of some Precambrian shales from the Canadian Shield. Chemical Geology, 28: 181-197.

Campbell, P., 1983. Bumps and bolides in the history of the Earth. Nature, 304: 584585.

Chambers, L.A. and Trudinger, P.A., 1978. Microbiological fractionation of stable sulfur isotopes: A review and critique. Geomicrobiology J., 1: 249-293. 
Claypool, G.E., Holser, W.T., Kaplan, I.R., Sakai, H. and Zak, I., 1980. The age curves of sulfur and oxygen isotopes in marine sulfate and their mutual interpretation. Chemical Geology, 28: 199-260.

CODATA, 1979. Report of the CODATA task group on chemical kinetics. CODATA Bulletin 33.

Drever, J.I., 1974. Geochemical model for the origin of Precambrian banded iron-formations. Geol. Soc. Am. Bull., 85: 1099-1106.

Edmond, J.M., Measures, C., Mangum, B., Grant, B., Sclater, F.R., Collier, R., Hudson, A., Godron, L.I. and Corliss, J.B., 1979a. On the formation of metal rich deposits at ridge crests. Earth Planet. Sci. Lett., 46: 19-30.

Edmond, J.M., Measures, C., McDuff, R.E., Chan, L.H., Collier, R., Grant, B., Gon, L.I. and Corliss, J.B., 1979b. Ridge crest hydrothermal activity and the balances of major and minor elements in the ocean: the Galapagos data. Earth Planet. Sci. Lett., 46: 1-18.

Emerson, S., 1976. Early diagenesis in anaerobic lake sediments: chemical equilibria in interstitial waters. Geochim. Cosmochim. Acta, 40: 925-934.

Emerson, S. and Widmer, G., 1978. Early diagenesis in anaerobic lake sediments II. Thermodynamic and kinetic factors controlling the formation of iron phosphate. Geochim. Cosmochim. Acta, 42: 1307-1316.

Ewers, W.E., 1980. Chemical conditions for the precipitation of banded iron-formations. In: P.H. Trudinger and M. Walter (Editors), Fourth International Symposium on Environmental Biogeochemistry. Springer-Verlag, New York, NY.

Froelich, P.N., Klinkhammer, G.P., Bender, M.L., Luedtke, N.A., Heath, G.R., Cullen, D., Dauphin, P., Hammond, D., Hartman, B. and Maynard, V., 1979. Early oxidation of organic matter in pelagic sediments of the eastern equatorial Atlantic: Suboxic diagenesis. Geochim. Cosmochim. Acta, 43: 1075-1090.

Garrels, R.M. and Mackenzie, F.T., 1971. Evolution of sedimentary rocks. W.W. Norton and Co., New York, NY, 397 pp.

Goodwin, A., Monster, J. and Thode, H.G., 1976. Carbon and sulfur isotope abundances in Archean iron-formations and Early Precambrian life. Econ. Geol., 71: 870-891.

Gordon, R.M., Martin, J.H. and Knauer, G.A., 1982. Iron in north east Pacific waters. Nature, 299: 611-612.

Gough, D.O., 1977. Theoretical predictions of variations of the solar output. In: O.R. White (Editor), The Solar Output and its Variations. University of Colorado Press, Boulder, CO, pp. 451-473.

Gough, D.O. and Weiss, N.O., 1976. The calibration of stellar convection theories. Mon. Not. R. Astron. Soc., 176: 589-607.

Harrison, A.G. and Thode, H.G., 1958. Mechanism of the bacterial reduction of sulfate from isotope fractionation studies. Trans. Faraday Soc., 54: 84-92.

Hattori, K., Campbell, F.A. and Krouse, H.R., 1983a. Sulfur isotope abundances in Aphebian clastic rocks: implications for the coeval atmosphere. Nature, 302: 323326.

Hattori, K., Krouse, H.R. and Campbell, F.A., 1983b. The start of sulfur oxidation in continental environments: about $2.2 \times 10^{9}$ years ago. Science, 221: 549-551.

Hayon, E., Treinin, A. and Wilf, J., 1972. Electronic spectra, photochemistry and autoxidation mechanisms of the sulfite-bisulfite-pyrosulfite systems. J. Am. Chem. Soc., $94: 47-57$.

Heald, E.F., Naughton, J. and Barnes, I.L., 1963. The chemistry of volcanic gases, use of equilibrium calculations in the interpretation of volcanic gas samples. J. Geophys. Res., 68: 545-557.

Holland, H.D., 1973. The oceans: A possible source of iron in iron-formations. Econ. Geol., 68: 1169-1172.

Holland, H.D., 1978. The Chemistry of the Atmosphere and Oceans. Wiley-Interscience, New York, NY, pp. 351. 
Holser, W.T. and Kaplan, I.R., 1966. Isotope geochemistry of sedimentary sulfates. Chem. Geol., 1: 93-135.

Kasting, J.F., Liu, S.C. and Donahue, T.M., 1979. Oxygen levels in the prebiological atmosphere. J. Geophys. Res., 84: 3097-3107.

Kasting, J.F. and Walker, J.C.G., 1981. Limits on oxygen concentration in the prebiological atmosphere and the rate of abiotic fixation of nitrogen. J. Geophys. Res., 86: $1147-1158$

Klein, C. and Bricker, O.P., 1977. Some aspects of the sedimentary and diagenetic environment of Proterozoic banded iron-formation. Econ. Geol., 72: 1457-1470.

Knoll, A.H., 1979. Archean photoautotrophy: some alternatives and limits. Origins of Life, 9: 313-327.

Lowe, D.R., 1980. Archean sedimentation. Ann. Rev. Earth Planet. Sci., 8: 145-167.

Lowe, D.R., 1982. Comparative sedimentology of the principal volcanic sequences of Archean greenstone belts in South Africa, Western Australia, and Canada: implications for crustal evolution. Precambrian Res., 17: 1-29.

McDuff, R.E. and Edmond, J.M., 1982. On the fate of sulfate during hydrothermal circulation at mid-ocean ridges. Earth Planet. Sci. Lett., 57: 117-132.

MacGeehan, P.J. and MacLean, W.H., 1980. An Archean sub-sea floor geothermal system, calc-alkali trends, and massive sulfide genesis. Nature, 286: 767-771.

Meybeck, M., 1979. Concentrations des eaux fluviales en elements majeurs et apports en solution aux oceans. Rev. Geol. Dynam. Geogr. Phys, 21: 215-246.

Moorbath, S., 1983. The most ancient rocks? Nature, 304: 585-586.

Newman, M.J. and Rood, R.T., 1977. Implications of solar evolution for the Earth's early atmosphere. Science, 198: 1035-1037.

Ohmoto, H., 1972. Systematics of sulfur and carbon isotopes in hydrothermal ore deposits. Econ. Geol., 67: 551-578.

Perry, R.A., Atkinson, R. and Pitts, J.N., 1976. Rate constants for the reactions $\mathrm{OH}+$ $\mathrm{H}_{2} \mathrm{~S} \rightarrow \mathrm{H}_{2} \mathrm{O}+\mathrm{SH}$ and $\mathrm{OH}+\mathrm{NH}_{3} \rightarrow \mathrm{H}_{2} \mathrm{O}+\mathrm{NH}_{2}$ over the temperature range 297427K. J. Chem. Phys., 64: 3237-3239.

Ronov, A.B. and Yaroshevskiy, A.A., 1967. Chemical structure of the Earth's crust. Geochemistry, pp. 1041-1066 (Trans. from Geokhimiya, No. 11, pp. 1285-1309, 1967).

Schidlowski, M., 1979. Antiquity and evolutionary status of bacterial sulfate reduction: sulfur isotope evidence. Origins of Life, 9: 299-311.

Schidlowski, M., Hayes, J.M. and Kaplan, I.R., 1983. Isotopic influences of ancient biochemistries: carbon, sulfur, hydrogen and nitrogen. In: J.W. Schopf (Editor), Earth's Earliest Biosphere: its Origin and Evolution. Princeton University Press, Princeton, NJ, pp. 149-186.

Skirrow, R. and Coleman, M.L., 1982. Origin of sulfur and geothermometry of hydrothermal sulfides from the Galapagos Rift, $86^{\circ} \mathrm{W}$. Nature, 299: 142-144.

Skyring, G.W. and Donnelly, T.H., 1982. Precambrian sulfur isotopes and a possible role for sulfite in the evolution of biological sulfate reduction. Precambrian Res., 17: 41-61.

Stevenson, D.J., 1983. The nature of the Earth prior to the rock record (The Hadean Earth). In: J.W. Schopf (Editor), The Earth's Earliest Biosphere: Its Origin and Evolution. Princeton University Press, Princeton, NJ, pp. 32-40.

Stoiber, R.E. and Jepsen, A., 1973. Sulfur dioxide contributions to the atmosphere by volcanos. Science, $182: 577-578$.

Thode, H.G. and Goodwin, A.M., 1983. Further sulfur and carbon isotope studies of Late Archean iron-formations of the Canadian Shield and the rise of sulfate reducing bacteria. Precambrian Res., 20: 337-356.

Van der Wood, R.B. and Thiemens, M.H., 1980. The fate of the hydroxyl radical in the earth's primitive atmosphere and the implications for the production of molecular oxygen. J. Geophys. Res., 85: 1605-1610. 
Veizer, J., 1983. Geologic evolution of the Archean-Early Proterozoic Earth. In: J.W. Schopf (Editor), Earth's Earliest Biosphere: Its Origin and Evolution. Princeton University Press, Princeton, NJ, pp. 240-259.

Veizer, J., Compston, W., Hoefs, J. and Nielsen, H., 1982. Mantle buffering of the early oceans. Naturwissenschaften, 69: 173-180.

Walker, J.C.G., 1977a. Evolution of the Atmosphere. Macmillan, New York, NY, pp. 318.

Walker, J.C.G., 1977b. Origin of the atmosphere: history of the release of volatiles from the solid earth. In: C. Ponnamperuma (Editor), Chemical Evolution of the Early Precambrian. Academic Press, New York, NY, pp. 1-11.

Walker, J.C.G., 1978. Oxygen and hydrogen in the primitive atmosphere. Pure Applied Geophys., 116: 222-231.

Walker, J.C.G., 1980. The oxygen cycle. In: O. Hutzinger (Editor), The Natural Environment and the Biogeochemical Cycles. Springer-Verlag, Berlin, pp. 87-104.

Walker, J.C.G., 1982. Climatic factors on the Archean earth. Paleogeogr., Paleoclimatol., Paleoecol., 40: 1-11.

Walker, J.C.G., 1983. Possible limits on the composition of the Archean ocean. Nature, 302: 518-520.

Walker, J.C.G., Klein, C., Schidlowski, M., Schopf, J.W. Stevenson, D.J. and Walter, M.R., 1983. Environmental evolution of the Archean-Early Proterozoic Earth. In: J.W. Schopf (Editor), Earth's Earliest Biosphere: Its Origin and Evolution. Princeton University Press, Princeton, NJ, pp. 260-290.

Winick, J.R. and Stewart, A.I.F., 1980. Photochemistry of $\mathrm{SO}_{2}$ in Venus upper cloud layers. J. Geophys. Res., 85: 7849-7860.

Wolery, T.J. and Sleep, N.H., 1976. Hydrothermal circulation and geochemical flux at mid-ocean ridges. J. Geol., 84: 249-275.

Zehnder, A.J.B. and Zinder, S.H., 1980. The sulfur cycle. In: O. Hutzinger (Editor), The Natural Environment and the Biogeochemical Cycles. Springer-Verlag, Berlin, pp. $105-145$. 